This item was submitted to Loughborough's Research Repository by the author.

Items in Figshare are protected by copyright, with all rights reserved, unless otherwise indicated.

\title{
Exploring the demands of assimilation among white ethnic majorities in Western Europe
}

PLEASE CITE THE PUBLISHED VERSION

http://dx.doi.org/10.1080/1369183X.2012.640015

PUBLISHER

(C) Routledge (Taylor \& Francis)

VERSION

AM (Accepted Manuscript)

LICENCE

CC BY-NC-ND 4.0

REPOSITORY RECORD

Antonsich, Marco. 2019. "Exploring the Demands of Assimilation Among White Ethnic Majorities in Western Europe". figshare. https://hdl.handle.net/2134/12996. 
This item was submitted to Loughborough's Institutional Repository (https://dspace.lboro.ac.uk/) by the author and is made available under the following Creative Commons Licence conditions.

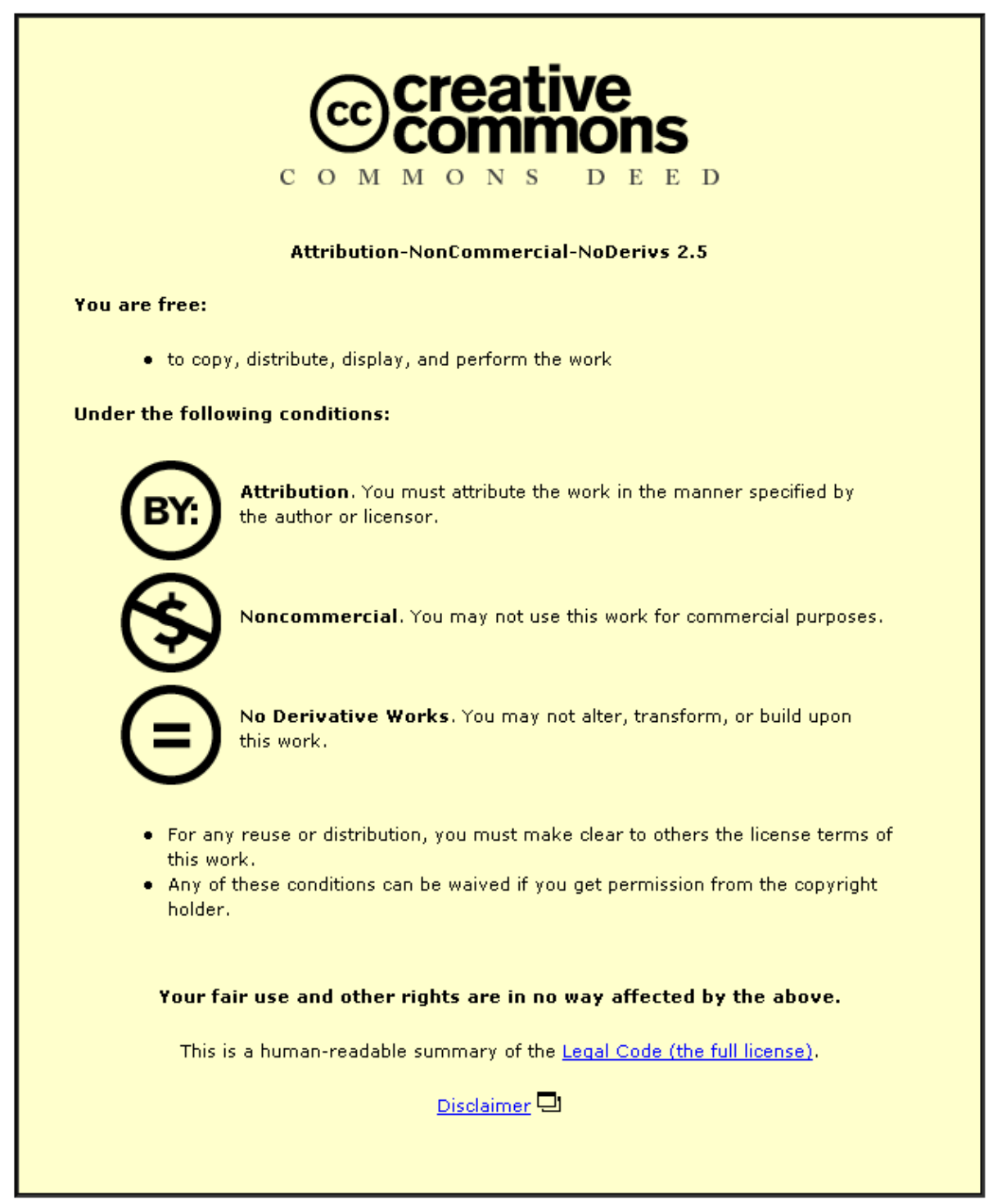

For the full text of this licence, please go to: http://creativecommons.org/licenses/by-nc-nd/2.5/ 


\title{
Exploring the demand of assimilation among white ethnic majorities in Western Europe
}

\begin{abstract}
Since the mid-1990s, assimilation has gradually regained momentum as both a normative and an analytical concept to understand the ways in which migrants are incorporated into societies at large. Although scholars have investigated various dimensions of this process, they have tended to privilege the experience of migrants themselves. Comparatively little attention has been dedicated to the perspective of the dominant groups, particularly in relation to what ethnic majority people demand migrants to do in relation to accept them. The present article explores this demand of assimilation by relying on qualitative data collected among white local elites in four regional case studies in Western Europe. The analysis reveals a different picture from the one usually portrayed by the 'new assimilation theory'. Accordingly, the article suggests rethinking assimilation in ways which incorporate more fully the plurality of demands put forward by dominant ethnic groups.
\end{abstract}

Keywords: assimilation, integration, multiculturalism, Western Europe

\section{Introduction}

During a conference on multiculturalism and integration held in Britain in 2005, Grillo (2007: 982) recalls that a person from the audience, anonymously identified as $\mathrm{Mr}$ S, asked to a distinguished panel of academics and politicians what he should do as a Muslim to show that he had integrated: 
I would like to know how I can prove that I'm a Muslim and I have integrated into society. Look at me. I wear British clothes. I speak broken English but, still, I speak English and I have got a beard. That gives away my identity. Some people would recognise who I am. Now, people ask me "Why don't you integrate?" and I say, "How do you mean?” And they can't answer me back because I go to schools, give talks about how to deal with racist incidents and very often the teachers ask me, 'Why don’t Muslims integrate?' I say, “What do you mean? I pay tax. I obey the law of the land”

This episode is not only telling of the contentious character of any integration process. It also reveals the demand of assimilation posed by the larger society to those members whose ethno-cultural and religious diversity appears 'too visible’, ‘too diverse’.

Across the Western world and, particularly, in Europe, the increasing uneasiness with this type of diversity is a phenomenon largely echoed by the mass-media and widely investigated in academic works. Some international and domestic events seem to have contributed to this present climate hostile to those who appear not 'to fit in': Islamist attacks against Western cities and the ensuing 'war on terror'; inter-racial unrests in the towns of Northern England (2001) and in the French banlieues (2005 and 2007); and, more recently, a severe economic downturn, which has triggered resentment against immigrants, accused of being the source of either the economic decline ('scapegoats') or unfair labour competition ('scabs’) (Gorodzeisky and Semyonov 2009: 404). Popular reactions across Western Europe in particular have demanded to curtail the flows of undocumented migrants and refugees, to expel 'undesired' ethnic communities (e.g., Roma in Italy and Northern Ireland), to remove from the public eye symbols of religious diversities (e.g., minarets in Switzerland and 'burka' in France, Belgium, and Italy), and to oblige the newcomers to plea allegiance to their new country. 
Fear and anxiety towards ethno-cultural and religious diversity have generated a new demand of assimilation, which has reversed the trend towards pluralism and multiculturalism of 1970s-1980s (Brubaker 2001; Joppke 2004). The shift from multiculturalism to assimilation has been a generalised tendency in many Western countries, also in those which had previously espoused forms of multiculturalism: the Netherlands (Entzinger 2003), Sweden (Joppke and Morawska 2003a), Germany (Brubaker 2001), Britain (Pilkington 2008), Australia (Vasta 2007), and the USA (Mitchell 2003). The return of assimilation has been apparent in public discourses, governmental policies, and academic debates. Survey data indeed suggest that hostility towards migrants, support for tougher immigration policies, and desire for cultural unity and homogeneity are both substantial and growing (Gorodzeisky and Semyonov 2009; Citrin and Sides 2008). Citizenship tests, pledges of allegiance, stricter naturalization laws, mandatory language and civic classes, restrictions on refugees and migration flows, and reinforced controls of undocumented migrants are now in place, to various degrees, in most Western countries. Scholars have also rediscovered, both in analytic and normative terms, the importance of the notion of assimilation (Brubaker 2001; International Migration Review 1997; Joppke and Morawska 2003b).

But what does it mean to assimilate? What does mainstream society demand $\mathrm{Mr}$ S and other fellow members who look or sound 'different' to do in order to accept them? Studies which analyse assimilation from the perspective of the dominant ethnic group are relatively scarce. These studies usually focus on the socio-demographic and contextual factors which explain positive/negative attitudes towards migrants (Pantoja 2006; Haubert and Fussell 2006; Hainmueller and Hiscox 2007; Leong 2008). Yet, within this perspective, assimilation is generally taken for granted. No attempts are 
made to explore the specific demands of assimilation put forward by the dominant group.

This article aims to discuss the notion of assimilation in relation to the plurality of demands posed by mainstream society to their ethno-culturally and religiously 'diverse' members. My discussion is articulated into two major parts. In the first part, I introduce the theoretical framework within which my argument is located. I trace the theoretical development of the notion of assimilation and I compare it to other similar notions (integration and acculturation) and to the notion which is usually portrayed as its opposite, multiculturalism. In the second part, I present and analyse empirical evidence coming from individual interviews with local elites in four regional case studies in Western Europe. This qualitative information is used to explore the assimilationist demand originating from white dominant ethnic groups and to serve as a basis to critically engage, in the final section, the academic revival of the notion of assimilation.

\section{From assimilation to multiculturalism and back}

Assimilation is a highly contentious term, which lacks a commonly shared definition (Kivisto 2005: 4). Both in public discourses and in academic works, the term is often used interchangeably with another vaguely defined and contested term, 'integration' (Bowskill et al. 2007). For some, this latter term also incorporates the notion of assimilation, along with other related terms: acculturation, accommodation, absorption, incorporation, inclusion, and participation (Castels et al. 2002: 126, 139; Favell 2001: 352). From this perspective, assimilation would be just one possible way in which migrants integrate into mainstream society. Yet, this interpretation, which originates from sociological studies, is not commonly accepted across social sciences. Psycholo- 
gists, for instance, treat acculturation as the all-encompassing term (Berry 2008). As a result, it is not uncommon to find assimilation, integration, and acculturation used as synonyms in the literature.

My goal here is not to draw conceptual lines between notions which often overlap. Some attempts in this sense have already been carried out (Castels et al. 2002), without dissipating completely the conceptual overlapping. This section, instead, aims to engage the notion of assimilation in historical perspective, in order to understand both its normative and analytical dimension and its demise and revival in relation to what is usually perceived as its opposite paradigm, i.e., multiculturalism. This would help contextualise the empirical data discussed in the next section.

As it well known, from the late $19^{\text {th }}$ century until the 1960 s assimilation was the prevailing approach adopted by countries of immigration towards newcomers (Castels et al. 2002; Joppke and Morawska 2003a). The general expectation was that they had to assimilate into the new culture and abandon their own traditions and social habits (Vasta 2007). Among others, Robert Park (1914) and Milton Gordon (1964) contributed to delineate a general theory of assimilation, tailored on the case of the United States. In both accounts, assimilation involved the acquisition of the dominant group's language, attitudes, life styles, modes of behaviour, values and, in Park, also religion (Alba and Nee 1997: 829; Kivisto 2005: 8-9). Cultural assimilation (defined as 'acculturation' by Gordon) was thought to be a spontaneous and inevitable process happening to individuals or groups by their entering in contact with a different culture. Yet, both Park and Gordon did not believe that this would per se mean the erasure of all signs of ethnic origin. To assimilate was, for Park, a way to enlarge one’s social horizons, as new cultural forms would add to and ‘modernise’ previous ones (Kivisto 2005: 8; Nagel 2009: 401). Similarly, Gordon believed that assimilation was a multi- 
stage process and the disappearance of any form of ethnic identity (what he called ‘identificational assimilation’) was not something inevitable. This could happen only as part of what he called 'structural assimilation', defined as the 'entrance of the minority group into the social cliques, clubs, and institutions of the core society at the primary group level' (Gordon 1964: 80). Far from being a spontaneous and inevitable process, structural assimilation entailed volition on both immigrants and mainstream society (Kivisto 2005: 14).

After World War II, assimilation fell gradually into disgrace (for a valuable discussion on the major factors which contributed to its demise see Joppke and Morawska 2003a). Starting in the late-1960s, new pluralist theories emerged, aimed at explaining the persistence of ethnic differences and new demands of recognition from marginalised social groups (e.g., blacks, women, and gays), indigenous peoples, and regionalist movements (Brubaker 2001; Kivisto 2005). These theories challenged the idea of a fixed and homogenous 'core culture' (coinciding with white middle-class culture) into which newcomers simply had to assimilate (Nagel 2009). Within this perspective, assimilation was regarded as a sort of 'dirty word' (Bauböck 1996b: 9), associated with coercive, ethnocentric, and patronising measures, often imposed by the state (Alba and Nee 1997: 827). Multiculturalism, on the contrary, emerged as the new prevailing paradigm, which, from the mid-1970s until the late-1990s, informed migration and racial policies of various Western countries, as well as the academic debate (Brubaker 2001; Joppke and Morawska 2003a). Within this paradigm, cultural diversity, rather than being something to be erased, was acknowledged and protected through state-funded initiatives (e.g. religious schools, education programs in foreign languages, ethnic mass-media, etc.). 
Towards the end of the 1990s, however, official multiculturalism came increasingly under attack, indirectly paving the way for an assimilationist revival (Brubaker 2001), which, in scholarly terms, has become known as 'new assimilation theory' (Alba and Nee 1997). This theory maintains that assimilation is still a powerful analytical tool for understanding the process of migrants' incorporation into contemporary societies. Thus, the old assimilationist theory should not be rejected, but amended. Accordingly, by drawing on Park's and Gordon's earlier insights, its proponents stress the reciprocal character of the assimilation process (Barkan 1995; DeWind and Kasinitz 1997), since both migrants and the receiving society are expected to undergo some form of change. Moreover, the new theory looks at migrants as active subjects in the process of 'becoming similar' - what Brubaker (2001: 534) calls the 'intransitive' meaning of assimilation, which he contrasts with the old 'transitive' meaning of 'making [someone] similar' through forced policies and programmes. Likewise, the new assimilation theory does not necessarily anticipate the erasure of migrants' culture of origin, since sameness (assimilation) and difference (multiculturalism and/or transnationalism) can actually coexist rather than being two dichotomous dimensions (Gans 1997: 877; Joppke and Morawska 2003a: 20; Kivisto 2005: 18, 24).

The 'new assimilation theory' has certainly contributed to advance the understanding of the process of incorporation of migrants into the receiving countries, by showing, among other things, how this process is not necessarily without 'bumps' (Gans 1992). It indeed entails various stages, since it takes place in different domains and times, involving multiple generations (Brubaker 2001: 544; Alba and Nee 1997: 827). Thus, it is also possible - as suggested by the 'segmented assimilation model' (Portes and Zhou 1993) - that second generation migrants become assimilated not into mainstream society's middle-class (upward mobility), but into its socio-economically 
deprived underclass (downward mobility) - an argument which still underlines the importance of the assimilationist drive in contemporary societies.

I would argue, however, that the new assimilation theory, like its classic version, tends to privilege one of the two sides involved in the assimilation process. The dominant group into whose social and cultural institutions migrants are supposed to assimilate is often overlooked. What this group exactly demands to migrants and what, therefore, assimilation means to them is often left unaddressed in the literature.

As a way to contribute to an understanding of the notion of assimilation from the 'other' side of this two-way process, the next section will examine public views of white ethnic majority individuals collected in four regional case studies in Western Europe. As discussed above, there is no lack of studies on the socio-demographic factors (e.g., age, education, political preference, etc.) which determine positive or negative attitudes towards migrants. Similarly, assimilationist scholars have clearly outlined the socio-economic dimensions (e.g., income, education, housing, etc.) where convergence between migrants and ethnic majority is used to assess the degree of assimilation. Relatively little, instead, is known on the meanings that assimilation assumes among ethnic majority people. I would argue that such a study is central to further advance our understanding of the assimilation process, as it complements the view based on migrants’ perspectives.

\section{The case study}

The present study is part of a larger research on the changing relationship between territory and identity in the age of globalisation, based on both quantitative (Standard Eurobarometer surveys) and qualitative (individual interviews and focus groups) data 
collected in Western Europe. For the purpose of the present article, only individual interviews with local elites (here defined as any person with a political, institutional or social role within the local society) will be used. During May 2005 and January 2006, I personally administered ninety-nine semi-structured individual interviews in four regions: Lombardia (Italy), Pirkanmaa (Finland), North-East of England (United Kingdom), and Languedoc-Roussillon (France). Interviewees were mainly chosen on the basis of their representativeness of the political parties active in the regions, even though representatives of labour and entrepreneurial organisations, civic officers and other local stakeholders (community organisations members, school and university staff) were also interviewed (see Table 1).

Table 1.Interviewees’ socio-geographical categories

\begin{tabular}{|l|c|c|c|c|c|}
\hline Interviewees & North East & Lombardia & Pirkanmaa & $\begin{array}{c}\text { Languedoc- } \\
\text { Roussillon }\end{array}$ & Total \\
\hline Politicians & 17 & 8 & 14 & 10 & $\mathbf{4 9}$ \\
\hline Labour representatives & 2 & 3 & 2 & 2 & $\mathbf{9}$ \\
\hline Entrepreneur representatives & 2 & 3 & 2 & 4 & $\mathbf{1 1}$ \\
\hline Civic officers & 5 & 2 & 5 & 5 & $\mathbf{1 7}$ \\
\hline Others & 4 & 2 & 3 & 4 & $\mathbf{1 3}$ \\
\hline Total & $\mathbf{3 0}$ & $\mathbf{1 8}$ & $\mathbf{2 6}$ & $\mathbf{2 5}$ & $\mathbf{9 9}$ \\
\hline
\end{tabular}

Men (seventy-one) largely outnumbered women (twenty-eight). Age varied widely, with the median value set somewhere around the low fifties. Level of education was also rather different, with a large number of respondents holding a university degree and a few interviewees also lacking a high-school degree. Information about income was not deliberately collected, yet personal details gathered during the interviews allow to affirm that the majority of the interviewees belonged to the middle-class, with few cases in the upper or lower classes. Interviews, which on average lasted about one hour, were conducted in the respondent's native language (except in Finland, where 
English was used) and in a place chosen by them (often the working place). ${ }^{1}$ The questions relevant to the present study referred to people's attitudes towards foreign migrants and their preference for multicultural or assimilationist approaches. Interviews were digitally recorded, transcribed, and coded by following an 'analytic induction’ approach (Crang 1997), which, echoing the grounded theory method, relies on the iterative process of going back and forth between original data and theoretical concepts in order to reach successively more abstract categorisations (Bryant and Charmaz 2007).

The choice of the four regional case studies was made on the basis of some preliminary statistical findings on Standard Eurobarometer and Eurostat data. ${ }^{2}$ The four regions capture a great variety of Western Europe’s different socio-economic conditions. Lombardia is one of the richest regions in Europe and a major 'engine' of the European economy, followed by Pirkanmaa, whose regional capital, Tampere, has long been on the forefront of the knowledge economy and information society (Castells and Himanen 2002). Down the ladder, the North-East of England is a region still heavily affected by the closure of the coal mining sector, with a relatively high level of unemployment, high numbers of people living on benefits and low level of education. Similarly, Languedoc-Roussillon is one of the poorest regions of France, with an economy essentially based on services for the domestic market and therefore rather impermeable to the effects of global economic competition (Giband 2005). In political terms, Lombardia is a region traditionally conservative, contrary to the North East of England, which has long been a stronghold of the Labour Party. A unique coalition of right and left parties ('brothers in arms') characterises Pirkanmaa’s regional capital (Tampere), while in the Languedoc-Roussillon the long-lasting tradition of the Midi 
Rouge (Genieys 1998) has recently given way to more centrist and rightist (National Front) parties.

Regarding the ethno-cultural 'diversity' of their population, the North-East of England and Languedoc-Roussillon belong to traditional countries of immigration, whereas the other two regions belong to countries which only in the last decade (Italy) or only in the last few years (Finland) have started receiving foreign immigrants, being previously countries of emigration themselves. This different past is somewhat reflected in the percentages of foreign citizens living in these countries (France: 5.8 per cent; the United Kingdom: 5.4 per cent; Italy: 4.6 per cent; and Finland: 2.2 per cent), whereas the same does not hold true at the regional level. In fact, both the North East of England (2.2 per cent) and Pirkanmaa (1.7 per cent) are regions with a low presence of foreign citizens, when compared with Lombardia (7.1 per cent) and Languedoc-Roussillon (5.7 per cent). ${ }^{3}$ These figures, however, do not take into consideration the presence of citizens of foreign origin and their children (i.e., second and third generation 'immigrants'), who are a significant component of the populations of France and the United Kingdom, whereas they are only about to emerge in Italy and in Finland. It is within this context that the opinions of the respondents should be located.

\section{The demand of assimilation among white ethnic majority people}

Contrary to the main tenet of the new assimilation theory, an overwhelming majority of interviewees, in all the four regional case studies, talked of assimilation in terms of a one-way process: ‘they’ have to assimilate into ‘our’ culture, values, ways of doing things, etc. While the specifics of this demand of assimilation will be analysed later in 
this section, here I would like to discuss a few other general points which emerged from the interviews.

The very few who acknowledged that assimilation and integration could also be a two-way process were located mainly in Finland, a country highly homogeneous both culturally and ethnically, where foreign immigration is a recent phenomenon. This might explain why Finnish interviewees were relatively more willing to welcome diversity - even though in its 'tamed' folkloristic and exotic aspects.

Across the case studies, it was generally a left-wing political view to characterise those who acknowledged assimilation as a mutual process - a point also confirmed by quantitative studies (Citrin and Sides 2008; Gorodzeisky and Semyonov 2009; Kessler and Freeman 2005). Within this perspective, the preservation of migrants' identity, traditions, and 'ways of doing' was accepted, even though at times this acceptance sounded more like tolerance or indifference rather than recognition, which scholars regard as an essential component in the construction of a viable multicultural society (Taylor et al. 1994). Consider, for instance, the following remark by an English male local councillor of an independent political group:

The guy that runs a shop [in my village] is Algerian, but he is accepted to me, he does his own things, he does not bother me, he does not bother anybody, he is accepted, there is no question.

In this perspective, any notion of mutual accommodation is absent and acceptance is 'granted' as long as the migrant 'does his own things', thus reproducing the highly debated notion of 'parallel lives’ put forward by the Cantle Report (Home Office, 2001).

Assimilation was also perceived by many interviewees as a natural, inevitable phenomenon, which occurs in time without any ad hoc state intervention. This view, 
which echoes the assimilationist theories of late nineteenth century USA (Kivisto 2005: 6), was articulated in relation to three major factors: employment, schooling, and housing. In other words, to have a job and a house and to send the children to school was deemed enough by many interviewees to assimilate the newcomers. Not surprisingly, this position was echoed in particular by French interviewees, as it reflects indeed the traditional French 'republican' model of migrants' assimilation (Bertossi 2007). This view does not only stress the importance of material factors in furthering assimilation - a point on which scholars also agree (Alba and Nee 1997: 835, 847) - but it also suggests that assimilation might take place through the mere happening of everyday life activities in working spaces, schools, sport clubs, shopping areas, etc. Quite a few interviewees in France, and a few also in the UK and Italy, across the political spectrum, supported this argument, by referring to what they saw as examples of successful integration of past domestic migrants (e.g., southern Italians moving to Northern Italy) and foreign migrants (e.g. Portuguese, Spanish and Polish migrants in France; Irish migrants in the UK). The following comments, respectively by a French male trade-unionist and an Italian male representative of an industrial association, exemplify this view:

We've got lots of Spanish communists and anarchists [who fled Franco's regime]...who were foreigners thirty years ago. Why did they integrate? Because there were jobs, lots of jobs [...]. Social ties come whenever there are jobs, when people manage to find an accommodation, a flat, where they can stay with their families [...].

I remember in the 1950s, when hundreds of [Italian] southerners were arriving to the train station... yes, they were still Italians, but at the time the terrone [derogative term for sourthern Italians] was really perceived as an alien in places like Como.

And then what happened?

Well, nobody think of it anymore. They integrated and they are perceived as normal Comaschi [people from Como]. At that time there was a big industrial push... but I still remember local people in the bars complaining about terroni 
who shout too much, who are dirty... the same narrow mentality which applies today against the extra-communitari [migrants from outside the EU].

This view appeared quite comforting to the interviewees, since it foresees assimilation in terms of a one-way, 'natural' process, which does not require any effort from the receiving society. Yet, it is a view which is obviously blind to both the mutated context within which recent migration has taken place and the more 'diverse' character of these migrants and their demands. The emergence of a post-Fordist model of production has indeed endangered the stability of the labour market, by increasing job competition particularly at its lower ends (Anderson et al. 2006; Commander et al. 2006), therefore hampering the ‘republican’ model of integration. Migrants have also become more 'diverse', not only because of the increased number of their countries of origin (Vertovec 2007), but also in relation to their 'culture', which, in certain cases, has found itself increasingly out of place in a time of 'war on terror' (Kibria 2008).

The specifics of the assimilation demand

What, however, did the interviewees specifically demand migrants to do in order to accept them? The emphasis on 'doing assimilation’ is not artificially imposed, but it actually emerge from the accounts of the interviewees. It reveals the importance of assimilation as a process, rather than a condition, as also suggested by Brubaker (2001: 534). It is through performance that assimilation becomes something visible in the everyday life, something which constructs the image of the newcomer and allows for the emergence of individual accounts of rejection or acceptance (Bell, 1999). Yet, contrary to Brubaker's notion of intransitive assimilation, the accounts of the inter- 
viewees reveal very little agency on the part of migrants. Performing assimilation in this context means to act, behave and, at times, also think and feel according to the demand of the dominant group, with hardly any space of negotiation.

In what follows, I have deliberately privileged a thematic rather than a geographic analysis, in order to highlight those opinions which recurred across a variety of geographic contexts rather than stressing the specifics of each context. This choice aims to avoid redundancy of information and facilitate a general understanding of the assimilation's demand. The analysis points to a commonality of views transversal across the geographic case studies and, at times, also across political ideologies. To be true, the comments of the interviewees reproduced positions already heard in public discourses. Yet, their systematic analysis allows, on the one hand, to emphasise the importance of 'performing' assimilation and, on the other hand, confirms that assimilation is not a binary condition (assimilated/not-assimilated), but a process which involves various dimensions and can therefore be open to political debate and contestation. Without pretending to be exhaustive, I believe that the following eight 'performative dimensions' are mostly relevant: knowing, participating, accepting, respecting, appreciating, behaving, and feeling. These dimensions, although only loosely, signal an increasing erasure of diversity and are indirectly revealing of the type of mainstream society into which immigrants assimilate.

By 'knowing' interviewees meant that immigrants should know the culture, the history, and the language of the receiving country, as well as its 'system', i.e. 'how things work here'. This demand of acculturation does not per se imply the erasure of migrants' culture of origin. To learn the language of the new country, for instance, does not obviously prevent retaining one’s native language (Bauböck 1996a: 13). Yet, knowing this language empowers the newcomer in the social, political, and economic 
sphere (Nagel and Staeheli 2005: 488), as for instance observed by a Finnish interviewee, a female local representative of a leftist party:

I don't understand that assimilation is the same thing [as] becom[ing] Finn. I think it is like... knowing Finnish culture so good that [one] can work, can participate here.

Please tell me more about it

My children... we live in that kind of area... where there a lot of foreign people and almost all my children's friends they come from different countries. They [keep] their own culture and their own families, but they speak Finnish and they play with my children. I think it is not complicated at all, but when I try to speak with the children's parents is quite impossible - they cannot speak Finnish, usually even English, they are afraid to go to society, or go to bank... they are some kind... they can’t manage here to ordinary life.

As this quote reveals, language is an essential element for 'participating', which can be regarded as an important component in itself to facilitate the acceptance of the newcomers. Two dimensions were often heard: community involvement and economic participation. The former refers to mundane acts of caring for, talking to, and socialise with your neighbour, as well as to support the local community. Not surprisingly, given public complaints about socio-spatial segregation in the UK (Home 2001; Phillips 2005), participation in the everyday life activities of the local community was mentioned particularly by English interviewees.

Economic participation refers to the contribution that migrants bring to the receiving society in terms of their labour - an essential factor in any process of assimilation (Alba and Nee 1997: 835). Italian and Finnish interviewees in particular stressed migrants’ economic contribution, since both in Lombardia (Mainardi 1998) and in Finland (Klinge 1990) ‘working hard’ plays a key role in shaping people’s selfimage. The following two quotes, respectively from an Italian female trade unionist and a Finnish male representative of a centrist party, substantiate this point: 
There are some [local] construction workers who after working everyday with Maghrebian workers say [in local dialect] 'well, he is good fellow, he does not understand anything, it's very hard to communicate, but he is good fellow, he works hard'.

I think work has taken a big role in our society, maybe too big, because we don't have [much] time for families [...]. But work is still gonna be the measure, how people are measuring the people who are coming here: are they working or not? [striking his fist on the desk]

Often perceived as a distinctive trait of both northern Italians and Finns, working ethic becomes the medium through which to include or exclude newcomers. Yet, as the following quote by an Italian male representative of an entrepreneurial organisation suggests, it is a form of assimilation which obviously has its limits:

[The presence of migrants] is perceived as also something which can be convenient. [There are] jobs which Italian workers don't want to do anymore, in the factories... We take what we need and for the rest we are rather indifferent. There is neither excessive fear, nor awareness that this can be transformed into a resource. We don't transform it into something really positive. [It is] only something we have become used to live with, in a rather opportunistic way: we use it, if we need it; otherwise, we just ignore it.

Not only, in case of an economic downturn, would this mode of assimilation not work anymore, since newcomers would be increasingly regarded as either scabs or scapegoats, as mentioned above. Yet, it is also a mode which remains blind to the cultural difference of the newcomer, thus negating any recognition of her/his own social identity and therefore preventing full acceptance - as studies on the civic unrest both in the French banlieues (Cesari 2005) and in the northern English towns (Pilkington 2008) suggest.

‘Accepting’, 'respecting’, and ‘appreciating’ our laws, culture, values, social rules, and way of life were terms equally heard across the four case studies, particularly among politically centre-rightist interviewees. Both the actual performance (i.e., the 
act which is demanded to them: accepting, respecting, and appreciating) and the immaterial objects towards which this act is directed (laws, values, etc.) suggest a demand of increasing sameness. To accept and respect the law is indeed part and parcel of any civic covenant which organises a territory and as such it demands cultural sameness only partially. Yet, to respect and accept the culture, values, social rules and way of life of a territory clearly speaks of an uneven power dynamic, marking that territory as the space of a given, dominant people who finally controls the accession to it. Similarly, moving from 'accepting' to 'respecting' and 'appreciating', the assimilative performance requested to the migrant is of a different nature. For instance, 'appreciating' implies acknowledging the positive features of the receiving country and might easily transform, as it happened in a couple of interviews with right-wing respondents, into a comparative discourse where our values are better than theirs. Within this context, no claims for alternative cultures or criticism towards the receiving society are possible, but only conformity.

Assimilation qua conformity to mainstream society emerged even more clearly in relation to the expected behaviour of the newcomers. 'Behaving' is indeed the most visible performative act and, therefore, it can easily expose the newcomer to possible discrimination/exclusion by the dominant group. The (erasure of the) visibility of migrants' diversity, as expressed in general behaviour, dressing, eating, living, leisure activities, and even thinking, was indeed a central issue in various interviews. 'When in Rome do as the Romans do' was a phrase which, although heard only from one English interviewee, captures the general attitude of many respondents across the four case studies, who did not always belong to conservative parties. The relevance of a conforming behaviour, however banal this might be, can be illustrated by the following quote from an English male conservative politician: 
I am teaching English literature to the children of an Iranian family, but they are completely at home in England. The mother, like any mother, makes me a cup of coffee. They are Muslims, but you know...

Performing banal acts which conform to and reproduce dominant social norms help reducing socio-cultural distance, while facilitating acceptance. The opposite is obviously true for behaviours which, instead, appear visibly 'out of place’ (Creswell 1996), like, for instance, wearing traditional clothes in public spaces, as noted, with a midst of bewilderment and irritation, by a French male socialist city councillor:

I am in charge of a neighbourhood where at five o'clock, at the end of the prayer... it's disturbing!

What?

To see so many people wearing their traditional Maghrebian dress...

Diversity should not be shown in public, as its visibility educes an implicit claim of recognition, which challenges socio-cultural conformity, homogeneity, and, in the case of France, also its ‘republican’ ideology. Diversity must instead be confined within the private sphere, as, for instance, remarked by the same previously quoted English interviewee:

When I worked in Ukraine people asked me 'what about Ukrainian communities in England?' I can't tell you, because I have never heard about it and that's the way it should be. They probably have their Ukrainian clubs, you know, where they have their own traditions, but you don't hear of them; they live like most all other people.

Other interviewees agreed on this public/private divide. The only diversity which was acceptable in public was one defused of its political charge, treated in folkloristic or exotic terms, which often referred to food (international cuisine, kebab res- 
taurants, etc.). Only a few, left-wing interviewees accepted the public manifestation of diverse cultural aspects, including religious practices.

Along with dressing, another major aspect of the behaviour of migrants lamented particularly by French and English interviewees was the habit of living separately from the rest of society. Very few interviewees acknowledged that this socio-spatial segregation could be a defensive reaction against discrimination and racism, as scholars have shown (Amin 2006; Ehrkamp 2005; Veronis 2007). The majority, across the political spectrum and, significantly, also a few people who affirmed to be in the past ‘strongly committed to multiculturalism', condemned the 'living on their own' of migrants. Physical concentration clearly made many interviewees feel unease, as it actually conveyed the image of migrants as a distinct 'out-group', which might threaten the socio-symbolic dominance of the ‘in-group’ (Citrin and Sides 2008). Particularly in France, the demands for breaking socio-spatial segregation clearly reproduced the French tradition of dealing with ethno-cultural diversity only in spatial terms (Bertossi 2007: 38), as if the aménagement du territoire (regional and urban planning) would automatically solve issues of social discrimination, racism, and inequality. The following quote, by a French male representative of a centre-right party, illustrates this point:

If you concentrate some people, as we did in the 1970s, in schools where there are 80per cent of immigrants, how can you think that we can have assimilation? It's impossible. We need to distribute them on the territory. We should kind of... this people, who did not assimilate... we should find the way to have them assimilate in a more open way, make them feel not rejected and therefore we should not have a concentration. The more concentration the more rejection, it's automatic.

Yet, ethnically mixed neighbourhoods do not lead per se to higher levels of social trust, as Putnam (2007) has shown for the case of the US and as one Finnish in- 
terviewee also acknowledged, reflecting on Finland's housing policy aimed at actively contrasting spatial segregation.

Finally, a very few interviewees, mainly sharing far-right political ideas, also talked of the need for migrants to fully identify with the new country. The newcomers must 'feel' French, Finnish, etc. This opinion, heard particularly in France, implicitly challenges the 'republican' model of assimilation. To be a French citizen is not enough to be considered French, in the absence of a clearly manifested feeling of identification, belonging, attachment and loyalty to the new homeland. As observed by a French male rightist interviewee, who consciously echoed an old-assimilationist American motto, 'La France: aimez-la ou quittez-la' (France: love it or leave it). Interviewees sharing this perspective also refused the possibility of double citizenship and identity. People have to choose. No transnational ties are admitted. Plus, anticipating what today has been formalised and institutionalised as the notion of 'earned citizenship’ (Dorsey and Díaz-Barriga 2007; Andreouli and Stockdale 2009), a couple of French interviewees demanded migrants to actively show their love for the country and 'earn' their new citizenship status through mundane (e.g. working) or illustrious (e.g., sport achievements) acts which could contribute to the material/intellectual advancement of their new homeland.

\section{Conclusion}

One of the main tenets of the new assimilation theory is that assimilation is not a oneway, but a two-way process, which involves change in both migrants and the receiving society. However, scholars have often privileged the study of only one of these two sides, analysing the different stages (economic, educational, social, and cultural) 
through which migrants are incorporated into the receiving society. Relatively few studies (apart from quantitative investigations into the socio-demographic factors which determine assimilationist attitudes) have analysed the demand of assimilation from the perspective of the ethnic majority group. What this people mean by the term assimilation has generally been overlooked.

As a way to fill this gap, the present article has examined local elites' opinions in four Western European regions. The findings reveal that, when analysed from the perspective of the members of the dominant ethnic group, assimilation cannot be treated as a singular, undifferentiated concept. Assimilation is instead associated with a plurality of performative dimensions. Through visible deeds, migrants must constantly show that they have met the various assimilationist demands advanced by the ethnic majority group. This also means that, from the perspective of this latter group, assimilation hardly mean mutual accommodation and change. In other words, assimilation is largely perceived as a one-way process.

In the absence of public opinion survey data on how assimilation is perceived by ethnic majority groups is difficult to comment on the extent to which the opinions of the local elites in this study reflect the opinions of the public at large. Yet, I should also say that, as a qualitative study, the present article aimed more at capturing variety of opinions across a geographically and socio-demographically diversified sample rather than searching for representativeness (Crang 1997). Clearly, some of the opinions expressed could be referred to certain categories of people rather than others, but in the absence of a quantitative analysis it would not be advisable to reach such a conclusion. Similar considerations apply to the geographic determinants. In this case, though, my hypothesis is that place-specific factors might have influenced the ways in which some opinions were framed, rather than actually determine them. 
With these limitations in mind, it is however useful to reflect on the extent to which the findings of this study might help refining a scholarly understanding of the assimilation process. There are a series of considerations which can be made. First, from a methodological perspective, given the plurality of meanings associated with the term assimilation, it becomes essential that studies on public attitudes detail which aspect of assimilation they aim to assess rather than treating assimilation as an undifferentiated and self-explanatory concept. Second, when analysed from the views of ethnic majority people, assimilation hardly stands for a status which can be finally acquired through a successful insertion into all the stages outlined by the (new) assimilation theory. On the contrary, assimilation resembles an unstable condition, which requires on the part of the migrant an incessant performance across a variety of domains - migrants must constantly show through performative acts that they have assimilated. This performance is demanded daily by ethnic majority group’s members, who perceive themselves as embodying the final authority that can 'grant' (but also postpone indefinitely) the status of 'assimilated'. In this sense, economic assimilation, educational assimilation and cultural assimilation cannot be regarded as objective stages of a linear or bumpy process, since they are imbued with an uneven power dynamic which marks them as provisional, constantly dependent on the subjective judgement of ethnic majority group’s members. This somewhat challenges the emphasis put by the new assimilation theory on migrants' agency and calls for studies which could analyse further the assimilation's uneven power dynamic and contextualise it in relation to the specific assimilationist demands put forward by a given society. Finally, and related to this point, the fact that an overwhelmingly majority of interviewees understood assimilation as a one way process should invite proponents of the new assimilation theory to look more carefully into their claim about mutual change. 
This claim risks indeed being rather prescriptive in the absence of empirical studies which can detail when, how, and under which circumstances a reciprocal change takes place.

Recently, Nagel (2009) has proposed to look at assimilation not in terms of observable patterns of similarity or dissimilarity, but as the discursive and material construction of 'the mainstream'. I believe that, within this perspective, the notion of assimilation avoids being trapped into some prescriptive form, but it remains open to the power dynamics involved in the assimilation process. Thus, in the present study, while demands of 'knowing', 'participating' and ‘accepting' point to a mainstream which can potentially accommodate diversity, demands of 'appreciating', 'behaving', and 'feeling' produce a mainstream which is more likely to exclude, marginalize, hide or erase diversity. Different assimilation demands implicate and are implicated in a different construction of 'the mainstream' and it is important to study them as a way to enrich our understanding of the multiple dynamics and (provisional) outcomes associated with the assimilation process.

\section{References}

Alba, R. and Nee, V. (1997) 'Rethinking assimilation theory for a new era of immigration', International Migration Review,31(4): 826-874.

Amin, A. (2006) 'The good city', Urban Studies,43(5/6): 1009-1023.

Anderson, B. et alii (2006) Fair enough? Central and East European migrants in lowwage employment in the UK.Oxford: COMPAS.

Andreouli, E. and Stockdale, J.E. (2009) 'Earned citizenship: Assumptions and implications', Journal of Immigration, Asylum and Nationality Law,23(2): 165-180. 
Barkan, E. (1995) 'Race, religion, and nationality in American society', Journal of American Ethnic History,14(2): 38-75.

Barry, B.M. (2001) Culture and equality. Cambridge: Polity Press.

Bauböck, R. (1996a) 'Introduction', in Bauböck et alii (eds) The challenge of diversity. Aldershot:Avebury, 7-21.

Bauböck, R. (1996b) 'Social and cultural integration in a civil society', in Bauböck et alii (eds) The challenge of diversity. Aldershot:Avebury, 67-131.

Bell, V. (ed.) (1999) Performativity and belonging. London: Sage.

Berry, J.W. (2008) 'Globalisation and acculturation', International Journal of Intercultural Relations,32: 328-336.

Bertossi, C. (2007) 'French and British models of integration', Working Paper no.46. Oxford: University of Oxford.

Bowskill, M. et alii (2007) 'The rhetoric of acculturation: When integration means assimilation', British Journal of Social Psychology,46: 793-813.

Brubaker, R. (2001) 'The return of assimilation? Changing perspectives on immigration and its sequels in France, Germany, and the United States', Ethnic and Racial Studies,24(4): 531-548.

Bryant, A. and Charmaz, K. (2007) Grounded theory. London: SAGE Publications.

Castells, M. and Himanen, P. (2002) The Information Society and the Welfare State. Oxford: OUP.

Castels, S. et alii (2002) Integration: Mapping the field. Oxford: University of Oxford.

Cesari, J. (2005) Ethnicity, Islam,and les banlieues. New York: SSRC.

Citrin, J. and Sides, J. (2008) 'Immigration and the imagined community in Europe and the United States', Political Studies,56: 33-56. 
Commander, S. et alii (2006) Migrating workers and jobs. Bonn: IZA.

Crang, M. (1997) 'Analyzing qualitative materials', in Flowerdew, R. and Martin, D. (eds) Methods in human geography. Edinburgh: Longman, 183-196.

Cresswell, T. (1996) In place, out of place. Minneapolis: University of Minnesota Press.

Dewind, J. and Kasinitz, P. (1997) 'Everything old is new again? Processes and theories of immigrant incorporation', International Migration Review,31(4): 10961111.

Dorsey, M.E. and Díaz-Barriga, M. (2007) 'Senator Barack Obama and Immigration Reform', Journal of Black Studies,38(1): 90-104.

Ehrkamp, P. (2005) 'Placing identities: Transnational practices and local attachments of Turkish immigrants in Germany', Journal of Ethnic and Migration Studies,31(2): 345-364.

Entzinger, H. (2003) 'The rise and fall of multiculturalism: The case of the Netherlands', in Joppke, C. and Morawska, E. (eds) Toward assimilation and citizenship. New York: Palgrave,87-109.

Favell, A. (2001) 'Integration policy and integration research in Europe', in Aleinikoff, T.A. and Klusmeyer, D.B. (eds) Citizenship today. Washington, D.C.: Carnegie Endowment, 349-399.

Gans, H.J. (1992) 'Ethnic invention and acculturation: A bumpy-line approach', Journal of American Ethnic History,12(1): 43-52.

Gans, H.J. (1997) 'Toward a reconcialition of 'assimilation' and 'pluralism", International Migration Review,31(4): 875-892.

Genieys, W. (1998) 'La 'grande transformation' du Midi Rouge', Pôle Sud,9: 3-6. 
Giband, D. (2005) 'Languedoc-Roussillon', in Giblin, B. (ed) Nouvelle géopolitique des régions francaises. Paris: Fayard, 733-781.

Gordon, M. (1964) Assimilation in American life. New York: OUP.

Gorodzeisky, A. and Semyonov, M. (2009) 'Terms of exclusion: public views towards admission and allocation of rights to immigrants in European countries', Ethnic and Racial Studies,32(3): 401-423.

Grillo, R. (2007) 'An excess of alterity? Debating difference in a multicultural society', Ethnic and Racial Studies,30(6): 979-998.

Hainmueller, J. and Hiscox, M.J. (2007) 'Educated preferences: Explaining attitudes toward immigration in Europe', International Organization, 61(spring): 399442.

Haubert, J. and Fussell, E. (2006) 'Explaining pro-immigrat sentiment in the U.S.', International Migration Review,40(3): 489-507.

Home Office (2001) Community Cohesion. London: The Stationery Office.

International Migration Review (1997) 'Special Issue: Immigrant Adaptation and Native-Born Responses in the Making of Americans ', International Migration Review,31(4).

Joppke, C. (2004) 'The retreat of multiculturalism in the liberal state', British Journal of Sociology,55(2): 237-257.

Joppke, C. and Morawska, E. (2003a) 'Integrating immigrants in liberal nation-states', in Joppke, C. and Morawska, E. (eds) Toward assimilation and citizenship. New York: Palgrave, 1-36.

Joppke, C. and Morawska, E. (2003b) Toward assimilation and citizenship. New York: Palgrave. 
Kessler, A.E. and Freeman, G.P. (2005) 'Public opinion in the EU on immigration from outside the community', Journal of Common Market Studies,43(4): 825850.

Kibria, N. (2008) 'The 'new Islam' and Bangladeshi youth in Britain and the US', Ethnic and Racial Studies,31(2): 243-266.

Kivisto, P. (2005) 'The revival of assimilation in historical perspective', in Kivisto, P. (ed) Incorporating diversity. Rethinking assimilation in a multicultural age. Boulder: Paradigm, 3-29.

Klinge, M. (1990) Let Us Be Finns. Helsinki: Otava.

Leong, C.-H. (2008) 'A multilevel research framework for the analyses of attitudes toward immigrants', International Journal of Intercultural Relations, 32: 115129.

Mainardi, D. (1998) L'Italia delle regioni. Milano: Bruno Mondadori.

Mitchell, K. (2003) 'Educating the national citizen in neoliberal times', Transactions of the Institute of British Geographers,28(4): 387-403.

Nagel, C.R. (2009) 'Rethinking geographies of assimilation', The Professional Geographer, 61(3): 400-407.

Nagel, C.R. and Staeheli, L. (2005) "'We're just like the Irish": Narratives of assimilation, belonging and citizenship amongst Arab-American activists', Citizenship Studies,9(5): 485-498.

Pantoja, A. (2006) 'Against the tide? Core American values and attitudes toward US immigration policy in the mid-1990s', Journal of Ethnic and Migration Studies,32(3): 515-531.

Park, R. (1914) 'Racial assimilation in secondary groups, with particular reference to the Negro', American Journal of Sociology,19(5): 606-623. 
Phillips, T. (2005) 'After 7/7: Sleepwalking to segregation'. Speech at Mancherster Town Hall, 22 September.

Pilkington, A. (2008) 'From institutional racism to community cohesion', Sociological Research Online,13(3).

Portes, A. and Zhou, M. (1993) 'The new second generation: segmented assimilation and its variants', Annals of the American Academy of Political and Social Science,530(1): 74-98.

Putnam, R.D. (2007) 'E Pluribus Unum: Diversity and community in the twenty-first century', Scandinavian Political Studies,30(2): 137-174.

Taylor, C. et alii (1994) Multiculturalism. Princeton: Princeton University Press.

Vasta, E. (2007) Accommodating diversity: why current critiques of multiculturalism miss the point. Oxford: Working Paper No.53, University of Oxford.

Vasta, E. (2009) The controllability of difference. Oxford: Working Paper No.71, University of Oxford.

Veronis, L. (2007) 'Strategic spatial essentialism: Latin Americans' real and imagined geographies of belonging in Toronto', Social\&Cultural Geography,8(3): 455473.

Vertovec, S. (2007) 'Super-diversity and its implications', Ethnic and Racial Studies, 30(6): 1024-1054.

\footnotetext{
${ }^{1}$ The Author is fluent in English, Italian, and French.

${ }^{2}$ The selection was based on cross-tabulating the results of a cluster analysis (using the significant predictors from a binary logistic model on European attachment - Eb 60.1, 2003) and Eurostat data (2001-
} 
2003) about regional GDP per capita (in Purchasing Power Parity values) for each region in the EU-15.

Further information on the sampling process is available from the author upon request.

${ }^{3}$ Data source: INSEE (France), National Statistics (United Kingdom), ISTAT (Italy), and Ti-

lastokeskus (Finland). Figures relate to the year 2005 (when the field work for the present research was carried out). 